\title{
DIMENSI KONSEP DIRI PADA PENDERITA HIV/AIDS
}

\author{
Susana Nurtanti*, Nita Yunianti Ratnasari \\ Akademi Keperawatan Giri Satria Husada Wonogiri \\ *Email: susan.alkuina@yahoo.com
}

\begin{abstract}
ABSTRAK
Permasalahan HIV dan AIDS menjadi tantangan kesehatan hampir di seluruh dunia, termasuk di Indonesia. Tujuan penelitian ini adalah untuk mengetahui tingkat dimensi konsep diri dari aspek usia, jenis kelamin, pendidikan dan pekerjaan pada ODHA di Klinik VCT RSUD dr. Soediran Mangun Sumarso Wonogiri. Desain penelitian ini adalah penelitian kuantitatif deskriptif dengan pendekatan cross-sectional. Instrumen dalam penelitian ini menggunakan kuesioner tentang konsep diri. Hasil analisis karakteristik responden berdasarkan usia menggambarkan jumlah tertinggi responden adalah usia 41 sampai dengan lebih dari 50 tahun, berjenis kelamin perempuan, berpendidikan sekolah dasar dan bekerja sebagai karyawan/buruh. Sebagian besar responden berdasarkan usia mempunyai dimensi konsep diri yang tinggi yaitu pada usia lansia akhir, berjenis kelamin perempuan. Pada bagian dimensi kritik diri sebagian besar yang memiliki kritik diri tinggi adalah laki laki. Berdasarkan tingkat pendidikan menunjukkan bahwa dimensi konsep diri responden dengan pendidikan SD lebih tinggi pada dimensi diri moral etik, diri pribadi, diri sosial dan kritik diri. Responden dengan pendidikan SMU mempunyai dimensi konsep diri yang tinggi pada dimensi diri fisik dan diri keluarga. Berdasarkan pekerjaan menunjukkan sebagian besar petani mempunyai tingkat dimensi konsep diri yang tinggi dibandingkan swasta/karyawan. Dari hasil penelitian menunjukkan bahwa sebagian besar tingkat dimensi respon konsep diri pada responden adalah tinggi dari aspek usia, jenis kelamin, tingkat pendidikan dan pekerjaan.
\end{abstract}

Kata kunci: Dimensi konsep diri, ODHA

\section{DIMENSIONS OF SELF-CONCEPT IN HIV / AIDS}

\begin{abstract}
The problems with HIV and AIDS pose health challenges in almost all the world, including in Indonesia. The objective of this study was to determine the level of dimensions of self-concept in PLWHA at the VCT Clinic at the RSUD dr. Soediran Mangun Sumarso Wonogiri Regency Indonesia. The design of this study is descriptive quantitative research with a cross-sectional approach. The instrument in this study used a questionnaire about self-concept. The results of the analysis characteristics of respondents based on age illustrate the highest number of respondents aged 41 to more than 50 years, female sex, elementary school education and working as an employee / laborer. Most respondents based on age have a high self-concept dimension, namely at the age of the elderly, female. In the dimension of self criticism, most of those who have high selfcriticism are men. Based on the level of education shows that the self-concept dimensions of respondents with elementary education are higher in the self dimension of moral ethics, personal self, social self and self criticism. Respondents with high school education have high self-concept dimensions in the dimensions of physical self and family self. Based on work shows that most farmers have a high level of self-concept dimensions compared to the private sector / employee.The conclusion of the study show that most of the dimensions of the self-concept response to respondents are high in terms of age, gender, education level and occupation.
\end{abstract}

Keywords: Self-concept dimensions, PLWHA

\section{PENDAHULUAN}

Permasalahan HIV dan AIDS menjadi tantangan kesehatan hampir di seluruh dunia, termasuk di Indonesia. Sampai dengan Juni 2018, HIV/AIDS telah dilaporkan keberadaannya oleh $433(84,2 \%)$ dari 514 Kabupaten/Kota di 34 Provinsi di Indonesia.(Indonesia, 2017). Menurut Kemenkes tahun 2017, persentase infeksi HIV tertinggi dilaporkan pada kelompok 
umur $25-49$ tahun $(69,6 \%)$, diikuti kelompok umur $20-24$ tahun $(17,8 \%)$ dan kelompok umur lebih sama dengan 50 tahun $(6,7 \%)$. Rasio HIV antara laki laki dan perempuan adalah $2: 1$. Sedangkan persentase AIDS tertinggi pada kelompok umur $30-39$ tahun $(38,6 \%)$ diikuti kelompok umur 20 - 29 tahun $(29,3 \%)$ dan kelompok umur 40 - 49 tahun $(16,5 \%)$. Rasio AIDS antara laki - laki dan perempuan adalah $2: 1$. (Indonesia, 2017)

Hasil Riskesdas 2018 di 32 Provinsi di Indonesia tentang Pengetahuan HIV/AIDS menunjukkan dari 21 pertanyaan, $4 \%$ mampu menjawab dengan benar $16-24$ pertanyaan, $2 \%$ tidak tahu tentang penyakit HIV/AIDS, 31,8 \% mampu menjawab 8- 15 pertanyaan dan $65,2 \%$ mampu menjawab 1 7 pertanyaan dengan benar. (Kesehatan, 2018) Hasil penelitian Yeni Tasa, dkk, 2016 menunjukkan bahwa pemanfaatan VCT oleh ibu rumah tangga terinfeksi HIV/AIDS di Kabupaten Belu berhubungan dengan tingkat pendidikan, persepsi tentang penyakit, persepsi tentang pelayanan kesehatan, pekerjaan suami, pendapatan keluarga, keterjangkauan, persepsi keparahan penyakit, dan persepsi stigma diri sendiri. Beberapa faktor tersebut akan mempengaruhi konsep diri ODHA termasuk persepsi stigma diri sendiri. (Tasa, Ludji, \& Rafael Paun, 2016)

Konsep diri merupakan identitas diri seseorang sebagai sebuah skema dasar yang terdiri dari kumpulan keyakinan dan sikap terhadap diri sendiri yang terorganisasi (Baron \& Donn, 2003). Hasil penelitian Nur Hasanah, dkk, 2012 menunjukkan bahwa konsep diri ODHA terbentuk melalui hasil interaksi sosial dengan lingkungan sekitarnya seperti istri, keluarga, teman dan orang lain. Label negatif dan diskriminasi yang diterima membuat kedua partisipan cenderung memiliki konsep diri negatif (merasa tidak berharga, tidak berguna, tidak berdaya, menurunnya motivasi untuk menjalani kehidupan dan menarik diri dari lingkungan). Konsep diri yang positif dapat dikembangkan melalui sosialisasi dengan orang lain, berbagi pengalaman dengan sesama ODHA sehingga ODHA akan memperoleh pengalaman dan semangat baru untuk tetap melanjutkan hidup. (Herani, Sarikusuma, \& Hasanah, 2012)

Kabupaten Wonogiri terletak di Provinsi Jawa Tengah Indonesia dengan jumlah penderita HIV/AIDS sebanyak 372 orang (Dinas Kesehatan Kabupaten Wonogiri, 2017). Namun, dari 372 orang yang terdaftar dengan HIV/AIDS hanya 90 orang yang secara teratur minum obat. Oleh sebab itu penulis melakukan penelitian kuantitatif studi cross-sectional deskriptif dengan tujuan untuk mengetahui tingkat dimensi konsep diri dari aspek usia, jenis kelamin, pendidikan dan pekerjaan pada ODHA di Klinik VCT RSUD dr. Soediran Mangun Sumarso Wonogiri. Hasil pengukuran tingkat dimensi konsep diri akan memberikan manfaat untuk memotivasi ODHA yang belum mempunyai kesadaran untuk melakukan pengobatan agar melakukan kunjungan ke klinik VCT melalui penelitian kuantitatif.

\section{METODE}

Penelitian ini merupakan penelitian kuantitatif studi cross-sectional deskriptif dengan menggunakan alat pengumpul data berupa kuesioner sebagai data primer. Penelitian ini dilaksanakan di Klinik VCT RSUD dr. Soediran Mangoen Soemarso Wonogiri pada bulan Januari sampai dengan Februari 2019 pada pasien HIV/AIDS yang berkunjung secara rutin di Klinik VCT. Populasi pada penelitian ini adalah seluruh pasien HIV/AIDS yang rutin berkunjung di Klinik VCT RSUD dr. Soediran Mangoen Soemarso Wonogiri dari Bulan Januari sampai dengan Bulan Februari 2019. Tehnik pengambilan sampling pada penelitian ini adalah purposive sampling.

Populasi dalam penelitian ini sebanyak 90 orang, yang mengikuti kelompok dukungan sebaya di Ruang Konseling dan Tes Sukarela (VCT) di Rumah Sakit Sudiran Mangun Sumarso Wonogiri. Sampel penelitian yang diambil 30 orang, setara dengan $35 \%$ dari penderita yang terdaftar dalam layanan selama periode pengumpulan data. Instrumen pengumpulan data menggunakan kuesioner tentang konsep diri untuk mengukur tingkat konsep diri responden. Formulir ini dirancang untuk dikelola sendiri, oleh karena itu, peneliti tetap di samping responden 
dalam mengisi kuesioner dan memberikan klarifikasi jika diperlukan. Kuesioner tentang konsep diri memuat diri fisik, diri moral etik, diri pribadi, diri keluarga, diri sosial, kritik diri yang terdiri dari 100 pertanyaan yang memuat item positif dan item negatif. Data yang diperoleh diolah dalam spreadsheet Excel dan diekspor ke SPSS versi 17.0 program. Untuk analisa statistik deskriptif menggunakan ; frekuensi absolut dan relatif, rata-rata, standar deviasi, koefisien variasi, dan nilai minimum dan maksimum.

\section{HASIL}

Tabel 1.

Karakteristik responden $(\mathrm{n}=30)$

\begin{tabular}{|c|c|c|}
\hline Umur & $\mathrm{f}$ & $\%$ \\
\hline $20-30$ & 6 & 20 \\
\hline $31-40$ & 6 & 20 \\
\hline $41-50$ & 9 & 30 \\
\hline$\geq 51$ & 9 & 30 \\
\hline \multicolumn{3}{|l|}{ Jenis Kelamin } \\
\hline Laki-laki & 13 & 43,3 \\
\hline \multicolumn{3}{|l|}{ Status Perkawinan } \\
\hline Menikah & 15 & 50 \\
\hline Single & 7 & 23,3 \\
\hline Janda/Duda & 8 & 26,7 \\
\hline \multicolumn{3}{|l|}{ Pendidikan } \\
\hline Tidak Bekerja & 1 & 3,33 \\
\hline Ibu Rumah Tangga & 6 & 20 \\
\hline Wiraswasta & 2 & 6,7 \\
\hline Karyawan Buruh (buruh,Karyawan) & 10 & 33,3 \\
\hline Petani & 11 & 36,7 \\
\hline
\end{tabular}

Tabel 2.

Jenis kelamin ODHA berdasarkan dimensi konsep diri $(n=30)$

\begin{tabular}{llccc}
\hline Domain diri & Jenis Kelamin & Dimensi konsep diri & $\mathrm{f}$ & $\%$ \\
\hline Fisik & Perempuan & Rendah & 6 & 20,0 \\
& & Tinggi & 11 & 36,7 \\
& Laki - laki & Rendah & 4 & 13,3 \\
& & Tinggi & 9 & 30,0 \\
\hline Moral etik & Perempuan & Rendah & 5 & 16,7 \\
& & Tinggi & 12 & 40,0 \\
& Laki - laki & Rendah & 6 & 20,0 \\
& & Tinggi & 7 & 23,3 \\
\hline Pribadi & Perempuan & Rendah & 5 & 16,7 \\
& & Tinggi & 12 & 40,0 \\
& Laki - laki & Rendah & 6 & 20,0 \\
& & Tinggi & 7 & 23,3 \\
\hline Keluarga & Perempuan & Rendah & 7 & 23,3 \\
& & Tinggi & 10 & 33,3 \\
& Laki - laki & Rendah & 5 & 16,7 \\
& & Tinggi & 8 & 26,7 \\
\hline Sosial & Perempuan & Rendah & 6 & 20,0 \\
& & Tinggi & 11 & 36,7 \\
& Laki - laki & Rendah & 7 & 23,3 \\
& & Tinggi & 6 & 20,0 \\
\hline Kritik diri & Perempuan & Rendah & 10 & 33,3 \\
& & Tinggi & 7 & 23,3 \\
& Laki - laki & Rendah & 4 & 13,3 \\
& & Tinggi & 9 & 40 \\
\hline
\end{tabular}


Tabel 3.

Usia ODHA berdasarkan domain konsep diri $(n=30)$

\begin{tabular}{|c|c|c|c|c|}
\hline Domain diri & Usia & Domain konsep diri & $\mathrm{f}$ & $\%$ \\
\hline \multirow[t]{8}{*}{ Fisik } & \multirow[t]{2}{*}{ Dewasa awal } & Rendah & 3 & 10 \\
\hline & & Tinggi & 3 & 10 \\
\hline & \multirow{4}{*}{$\begin{array}{l}\text { Dewasa Akhir } \\
\text { Lansia Awal }\end{array}$} & Rendah & 1 & 3,3 \\
\hline & & Tinggi & 5 & 16,7 \\
\hline & & Rendah & 5 & 16,7 \\
\hline & & Tinggi & 4 & 13,3 \\
\hline & \multirow[t]{2}{*}{ Lansia Akhir } & Rendah & 1 & 3,3 \\
\hline & & Tinggi & 8 & 26,7 \\
\hline \multirow[t]{8}{*}{ Moral Etik } & \multirow[t]{2}{*}{ Dewasa awal } & Rendah & 1 & 3,3 \\
\hline & & Tinggi & 5 & 16,7 \\
\hline & \multirow[t]{3}{*}{ Dewasa Akhir } & Rendah & 4 & 13,3 \\
\hline & & Tinggi & 2 & 16,7 \\
\hline & & Rendah & 4 & 13,3 \\
\hline & \multirow{3}{*}{$\begin{array}{l}\text { Lansia Awal } \\
\text { Lansia Akhir }\end{array}$} & Tinggi & 5 & 16,7 \\
\hline & & Rendah & 2 & 6,7 \\
\hline & & Tinggi & 7 & 23,3 \\
\hline \multirow[t]{8}{*}{ Pribadi } & \multirow[t]{2}{*}{ Dewasa awal } & Rendah & 1 & 3,3 \\
\hline & & Tinggi & 5 & 16,7 \\
\hline & \multirow[t]{3}{*}{ Dewasa Akhir } & Rendah & 4 & 13,3 \\
\hline & & Tinggi & 2 & 16,7 \\
\hline & & Rendah & 4 & 13,3 \\
\hline & \multirow{3}{*}{$\begin{array}{l}\text { Lansia Awal } \\
\text { Lansia Akhir }\end{array}$} & Tinggi & 5 & 16,7 \\
\hline & & Rendah & 2 & 6,7 \\
\hline & & Tinggi & 7 & 23,3 \\
\hline \multirow[t]{8}{*}{ Keluarga } & \multirow[t]{2}{*}{ Dewasa awal } & Rendah & 1 & 3,3 \\
\hline & & Tinggi & 5 & 16,7 \\
\hline & \multirow[t]{3}{*}{ Dewasa Akhir } & Rendah & 3 & 10 \\
\hline & & Tinggi & 3 & 10 \\
\hline & & Rendah & 4 & 13,3 \\
\hline & Lansia Awal & Tinggi & 5 & 16,7 \\
\hline & Lansia Akhir & Rendah & 4 & 13,3 \\
\hline & & Tinggi & 5 & 16,7 \\
\hline \multirow[t]{8}{*}{ Sosial } & \multirow[t]{2}{*}{ Dewasa awal } & Rendah & 4 & 13,3 \\
\hline & & Tinggi & 2 & 6,7 \\
\hline & \multirow[t]{3}{*}{ Dewasa Akhir } & Rendah & 1 & 3,3 \\
\hline & & Tingg & 5 & 16,7 \\
\hline & & Rendah & 6 & 20 \\
\hline & \multirow{3}{*}{$\begin{array}{l}\text { Lansia Awal } \\
\text { Lansia Akhir }\end{array}$} & Tinggi & 3 & 16,7 \\
\hline & & Rendah & 2 & 6,7 \\
\hline & & Tinggi & 7 & 23,3 \\
\hline \multirow[t]{8}{*}{ Kritik diri } & \multirow[t]{2}{*}{ Dewasa awal } & Rendah & 4 & 13,3 \\
\hline & & Tinggi & 2 & 6,7 \\
\hline & \multirow[t]{3}{*}{ Dewasa Akhir } & Rendah & 3 & 10 \\
\hline & & Tinggi & 3 & 10 \\
\hline & & Rendah & 4 & 13,3 \\
\hline & Lansia Awal & Tinggi & 5 & 16,7 \\
\hline & Lansia Akhir & Rendah & 3 & 10 \\
\hline & & Tinggi & 6 & 20 \\
\hline
\end{tabular}


Tabel 4.

Pendidikan ODHA berdasarkan domain konsep diri $(n=30)$

\begin{tabular}{|c|c|c|c|c|}
\hline Domain diri & Pendidikan & Domain konsep diri & $\mathrm{f}$ & $\%$ \\
\hline \multirow{6}{*}{ Fisik } & SD & Rendah & 1 & 3,3 \\
\hline & & Tinggi & 9 & 30 \\
\hline & SMP & Rendah & 3 & 10 \\
\hline & SMU/Sederajad & Tinggi & 2 & 6,7 \\
\hline & & Rendah & 6 & 20 \\
\hline & & Tinggi & 9 & 30 \\
\hline \multirow[t]{6}{*}{ Moral etik } & SD & Rendah & 2 & 6,7 \\
\hline & & Tinggi & 8 & 26,7 \\
\hline & SMP & Rendah & 1 & 3,3 \\
\hline & & Tinggi & 4 & 13,3 \\
\hline & & Rendah & 8 & 26,7 \\
\hline & SMU/Sederajad & Tinggi & 7 & 23,3 \\
\hline \multirow[t]{6}{*}{ Pribadi } & SD & Rendah & 2 & 6,7 \\
\hline & & Tinggi & 8 & 26,7 \\
\hline & SMP & Rendah & 1 & 3,3 \\
\hline & SMU/Sederajad & Tinggi & 4 & 13,3 \\
\hline & & Rendah & 8 & 26,7 \\
\hline & & Tinggi & 7 & 23,3 \\
\hline \multirow[t]{6}{*}{ Keluarga } & SD & Rendah & 4 & 13,3 \\
\hline & & Tinggi & 6 & 20 \\
\hline & SMP & Rendah & 0 & 0 \\
\hline & & Tinggi & 5 & 16,7 \\
\hline & & Rendah & 8 & 26,7 \\
\hline & SMU/Sederajad & Tinggi & 7 & 23,3 \\
\hline \multirow[t]{6}{*}{ Sosial } & SD & Rendah & 2 & 6,7 \\
\hline & & Tinggi & 8 & 26,7 \\
\hline & SMP & Rendah & 3 & 10 \\
\hline & & Tinggi & 2 & 6,7 \\
\hline & & Rendah & 8 & 26,7 \\
\hline & SMU/Sederajad & Tinggi & 7 & 23,3 \\
\hline \multirow[t]{6}{*}{ Kritik diri } & SD & Rendah & 2 & 6,7 \\
\hline & & Tinggi & 8 & 26,7 \\
\hline & SMP & Rendah & 3 & 10 \\
\hline & & Tinggi & 2 & 6,7 \\
\hline & & Rendah & 8 & 26,7 \\
\hline & SMU/Sederajad & Tinggi & 7 & 23,3 \\
\hline \multirow[t]{10}{*}{ Sosial } & Tidak bekerja & Rendah & 0 & 0 \\
\hline & & Tinggi & 1 & 3,3 \\
\hline & IRT & Rendah & 3 & 10,0 \\
\hline & & Tinggi & 3 & 10,0 \\
\hline & & Rendah & 1 & 3,3 \\
\hline & Wiraswasta & Tinggi & 1 & 3,3 \\
\hline & Swasta/Karyawan & Rendah & 5 & 16,7 \\
\hline & & Tinggi & 5 & 16,7 \\
\hline & & Rendah & 3 & 10,0 \\
\hline & Petani & Tinggi & 8 & 26,7 \\
\hline
\end{tabular}


Tabel 5.

Pekerjaan ODHA berdasarkan domain konsep diri $(n=30)$

\begin{tabular}{|c|c|c|c|c|}
\hline Domain diri & Pekerjaan & Domain konsep diri & $\mathrm{f}$ & $\%$ \\
\hline \multirow[t]{10}{*}{ Fisik } & \multirow[t]{2}{*}{ Tidak bekerja } & Rendah & 1 & 3,3 \\
\hline & & Tinggi & 0 & 0 \\
\hline & IRT & Rendah & 4 & 13,3 \\
\hline & \multirow[t]{3}{*}{ Wiraswasta } & Tinggi & 2 & 6,7 \\
\hline & & Rendah & 0 & 0 \\
\hline & & Tinggi & 2 & 6,7 \\
\hline & \multirow[t]{3}{*}{ Swasta/Karyawan } & Rendah & 4 & 13,3 \\
\hline & & Tinggi & 6 & 20,0 \\
\hline & & Rendah & 1 & 3,3 \\
\hline & Petani & Tinggi & 10 & 33,3 \\
\hline \multirow[t]{10}{*}{ Moral etik } & \multirow[t]{2}{*}{ Tidak bekerja } & Rendah & 0 & 0 \\
\hline & & Tinggi & 1 & 3,3 \\
\hline & \multirow[t]{3}{*}{ IRT } & Rendah & 1 & 3,3 \\
\hline & & Tinggi & 5 & 16,7 \\
\hline & & Rendah & 0 & 0 \\
\hline & \multirow{4}{*}{$\begin{array}{l}\text { Wiraswasta } \\
\text { Swasta/Karyawan }\end{array}$} & Tinggi & 2 & 6,7 \\
\hline & & Rendah & 7 & 23,3 \\
\hline & & Tinggi & 3 & 10,0 \\
\hline & & Rendah & 3 & 10,0 \\
\hline & Petani & Tinggi & 8 & 26,7 \\
\hline \multirow[t]{10}{*}{ Pribadi } & Tidak bekerja & Rendah & 0 & 0 \\
\hline & & Tinggi & 1 & 3,3 \\
\hline & \multirow[t]{3}{*}{ IRT } & Rendah & 1 & 3,3 \\
\hline & & Tinggi & 5 & 16,7 \\
\hline & & Rendah & 0 & 0 \\
\hline & \multirow{4}{*}{$\begin{array}{l}\text { Wiraswasta } \\
\text { Swasta/Karyawan }\end{array}$} & Tinggi & 2 & 6,7 \\
\hline & & Rendah & 7 & 23,3 \\
\hline & & Tinggi & 3 & 10,0 \\
\hline & & Rendah & 3 & 10,0 \\
\hline & Petani & Tinggi & 8 & 26,7 \\
\hline \multirow[t]{10}{*}{ Keluarga } & \multirow[t]{2}{*}{ Tidak bekerja } & Rendah & 0 & 0 \\
\hline & & Tinggi & 1 & 3,3 \\
\hline & IRT & Rendah & 1 & 3,3 \\
\hline & \multirow[t]{3}{*}{ Wiraswasta } & Tinggi & 5 & 16,7 \\
\hline & & Rendah & 1 & 0 \\
\hline & & Tinggi & 1 & 6,7 \\
\hline & \multirow[t]{3}{*}{ Swasta/Karyawan } & Rendah & 6 & 20 \\
\hline & & Tinggi & 4 & 10,0 \\
\hline & & Rendah & 4 & 10,0 \\
\hline & Petani & Tinggi & 7 & 23,3 \\
\hline \multirow[t]{10}{*}{ Kritik diri } & \multirow[t]{2}{*}{ Tidak bekerja } & Rendah & 0 & 0 \\
\hline & & Tinggi & 1 & 3,3 \\
\hline & IRT & Rendah & 3 & 10,0 \\
\hline & \multirow[t]{3}{*}{ Wiraswasta } & Tinggi & 3 & 10,0 \\
\hline & & Rendah & 0 & 0 \\
\hline & & Tinggi & 2 & 6,7 \\
\hline & \multirow{3}{*}{ Swasta/Karyawan } & Rendah & 5 & 16,7 \\
\hline & & Tinggi & 5 & 16,7 \\
\hline & & Rendah & 5 & 16,7 \\
\hline & Petani & Tinggi & 6 & 20,0 \\
\hline
\end{tabular}




\section{PEMBAHASAN}

Usia ODHA

Berdasarkan total hasil persentase, karakteristik responden berdasarkan usia menggambarkan jumlah tertinggi responden adalah usia 41 - lebih dari 50 tahun yaitu $60 \%$ dan terendah di usia 20 - 40 tahun yaitu $40 \%$. Dalam hal usia masuk ke dalam tahap perkembangan lansia awal dan akhir. Usia tua adalah periode penutup dalam rentang hidup seseorang, yaitu suatu periode dimana seseorang telah " beranjak jauh" dari periode terdahulu yang lebih menyenangkan atau beranjak dari waktu yang penuh dengan manfaat. Pada masa ini seseorang tidak lagi bersifat evolusional, akan tetapi mereka mulai mengalami kemunduran bertahap yang disebut dengan menua. Perubahan tersebut meliputi fisik, mental, maupun psikologisnya. Perubahan psikologisnya terjadi karena munculnya sikap tidak senang terhadap diri sendiri, orang lain, pekerjaan dan kehidupan yang pada umumnya terjadi pada masa uzur.(Herani et al., 2012) Hal ini yang dapat mempengaruhi terjadinya gangguan pada kosep diri, dimana lansia dengan konsisi penurunan psikologis dan mengalami penyakit HIV/AIDS. Hasil penelitian ini sesuai dengan hasil Pusat Data dan Informasi Kementerian Republik Indonesia tentang Situasi dan Analisis HIV AIDS yang menyebutkan bahwa jumlah infeksi HIV yang dilaporkan oleh kelompok usia dari tahun 2010 hingga September 2014 terjadi pada kelompok umur 25-49 tahun, diikuti usia 20 - 24 tahun(Kesehatan, 2018).

\section{Jenis kelamin ODHA}

Karakteristik responden berdasarkan jenis kelamin sejumlah 13 responden laki-laki atau $43,3 \%$ dan sebanyak 17 responden perempuan atau $56,6 \%$. Hal ini sesuai dengan penelitian Marni, dkk bahwa wanita dengan HIV/AIDS terinfeksi oleh suami mereka karena suaminya yang mempunyai pasangan yang lain. "Women with HIV/AIDS were infected by their husbands because the husbands have other partners". (Marni, RN, Susana Nurtanti, RN, Sri Handayani, RN, Nita Yunianti Ratnasari, RN, \& Tantut Susanto,MN,RN MN,RN,PHN, 2018). Hal ini sesuai dengan laporan UNAIDS yang menyebutkan $90 \%$ perempuan yang hidup dengan HIV positif di Asia tertular dari suami atau pasangan seksual. Data juga menunjukkan bahwa transmisi dari pria pengidap HIV/AIDS kepada wanita pasangannya lebih sering terjadi dibandingkan dari wanita pengidap HIV kepada pria pasangannya

Berdasarkan penelitian Khoiriyah Isni menyebutkan bahwa faktor resiko penularan kasus HIV pada ibu rumah tangga menduduki peringkat kedua.(Isni, 2016). Penelitian yang sama oleh Yeni Tasa menyebutkan ibu rumah tangga merupakan penderita HIV/AIDS terbanyak di Kabupaten Belu(Tasa et al., 2016). Sesuai dengan hasil penelitian sebagian besar responden adalah wanita dengan suami yang bekerja di luar kota.

\section{Pendidikan ODHA}

Distribusi frekuensi responden yang, responden yang berpendidikan Sekolah Dasar sebanyak 15 atau $50 \%$, lulusan SMP sejumlah 5 atau $16,7 \%$ responden dan lulusan SMU sebanyak 10 atau 33,3\% responden. Sesuai dengan penetian Yeni Tasa, dkk sebagian besar responden termasuk berpendidikan rendah yaitu tidak tamat SD, tamat SD atau SLTP. (Tasa et al., 2016). Selain SD tingkat pendidikan responden adalah SLTA. Data ini sesuai dengan beberapa penelitian bahwa sebagian besar penderita HIV/AIDS memiliki pendidikan SLTA. (Ibrahim, H, Rahayuwati, \& Nurmalisa, 2017).

\section{Pekerjaan ODHA}

Distribusi frekuensi responden berdasarkan pekerjaan sebagain besar adalah sebagai karyawan/buruh. Sesuai dengan penelitian sebelumnya dalam Kusman, Ibrahim, dkk melaporkan bahwa angka kejadian HIV/AIDS cukup tinggi pada pekerja terutama karyawan swasta. Komisi penanggulangan AIDS (KPA) Kota Bandung melaporkan hal serupa dimana pekerjaan terbanyak pada pasien HIV/AIDS yaitu pada pekerja swasta $(26,65 \%)$, dan wiraswasta (16,75\%). (Ibrahim et al., 2017).

\section{Tingkat Dimensi Konsep Diri ODHA Berdasarkan Usia}

Sebagian besar responden berdasarkan usia mempunyai dimensi konsep diri yang tinggi 
yaitu pada usia lansia akhir. Konsep diri positif (tinggi) adalah pemahaman dan penerimaan diri terhadap sejumlah fakta yang bermacam - macam sehubungan dengan diri. Individu yang memiliki konsep diri positif (tinggi) akan merancang tujuan tujuan sesuai dengan realitas, yaitu tujuan yang memiliki kemungkinan besar untuk dicapai, mampu menghadapi kehidupan kedepannya serta menganggap bahwa hidup adalah proses penemuan (Herani et al., 2012).

Karakteristik responden berdasarkan usia menggambarkan jumlah tertinggi responden adalah usia 41 - lebih dari 50 tahun yaitu $60 \%$. Usia tua adalah periode penutup dalam rentang hidup seseorang, yaitu suatu periode dimana seseorang telah " beranjak jauh" dari periode terdahulu yang lebih menyenangkan atau beranjak dari waktu yang penuh dengan manfaat. Pada masa ini seseorang tidak lagi bersifat evolusional, akan tetapi mereka mulai mengalami kemunduran bertahap yang disebut dengan menua. Perubahan tersebut meliputi fisik, mental, maupun psikologisnya. Perubahan psikologisnya terjadi karena munculnya sikap tidak senang terhadap diri sendiri, orang lain, pekerjaan dan kehidupan yang pada umumnya terjadi pada masa uzur.(Herani et al., 2012).

Tingkat dimensi konsep diri berdasarkan usia responden dalam penelitian ini adalah tinggi pada usia lansia akhir. Konsep diri positif yang dimiliki dapat ditunjukkan melalui kemampuannya menerima kondisi dan keadaan diri pada saat kini, bersikap lebih realistik, objektif dan tidak menunjukkan ketegangan emosional yang berlebihan. Dengan demikian ODHA dapat menjalani kehidupan selanjutnya secara efektif, efisien dan bertanggung jawab. (SurahmaWahyu, Taufik, \& Asmidirlilyas, 2012).

\section{Karakteristik Responden ODHA Berdasarkan Jenis Kelamin}

Dilihat dari hasil prosentase karakteristik responden ODHA menurut jenis kelamin sebanyak 17 atau $56,6 \%$ responden berjenis kelamin perempuan dan 13 atau 43,3\% dengan jenis kelamin laki laki ini menunjukkan bahwa proporsi perempuan lebih banyak dibandingkan laki laki karena jumlah dari responden ODHA lebih banyak didominasi oleh perempuan. Perbedaan jumlah proporsi menunjukkan karakteristik dimensi konsep diri yang berbeda untuk masing masing jenis kelamin. Konsep diri ODHA berbeda antara satu orang dengan yang lainnya. ODHA menilai dirinya sendiri secara positif, namun ada yang masih merasakan penyesalan kekecewaan dan kemarahan. Penilaian terhadap citra diri secara umum baik, namun ada ODHA yang menilai dirinya sebagai orang yang kecewa dan menyesal karena telah memilih pasangan hidup yang salah sehingga akhirnya mengalami kehidupan seperti ini.(A. Nelson Aritonang et al., 2014).

Responden dalam penelitian ini berdasarkan jenis kelamin sebagain besar adalah perempuan dan mempunyai tingkat dimensi konsep diri yang tinggi. Pada bagian dimensi kritik diri sebagian besar memiliki kritik diri yang tinggi adalah laki laki. Sesuai dengan hasil penelitian Ida Ayu, dkk memperlihatkan bahwa terdapat 9 gambaran penerimaan diri pada perempuan di Bali pengidap HIV/AIDS yaitu selalu bersyukur, optimis dan selalu melakukan yang terbaik, menghargai diri sendiri, pembuktian diri, memiliki hak dan merasa sejajar dengan orang lain, tidak ingin diperlakukan berbeda ingin membantu serta dapat berbagi dengan orang lain, instropeksi diri, mendekatkan diri pada Tuhan. (Ayu, Putri, \& Tobing, 2016).

\section{Karakteristik Responden ODHA Berdasarkan Tingkat Pendidikan}

Persentase hasil karakteristik responden ODHA berdasarkan tingkat pendidikan menunjukkan jumlah tertinggi responden lulusan SD yaitu 15 atau $50,0 \%$, terendah SMP 5 atau $16,7 \%$ dan lulusan SMU sebanyak 10 atau 33,3\% responden. Dari hasil penelitian dimensi diri moral etik, diri pribadi, diri sosial dan kritik diri berdasarkan pendidikan menunjukkan bahwa sebagian besar dimensi konsep diri pendidikan SD lebih tinggi dibandingkan dengan yang lain. Pada dimensi diri fisik dan diri keluarga responden dengan pendidikan SMU mempunyai dimensi konsep diri yang tinggi. Data ini sesuai dengan beberapa penelitian bahwa sebagian besar para penderita HIV/AIDS memiliki tingkat pendidikan 
SLTA. Astuti, Yosep \& susanti 2015.(Ibrahim et al., 2017)

Sesuai penelitian Konsep diri adalah cara individu yang melihat pribadinya secara utuh menyangkut emosi, fisik, intelektual, sosial dan spiritual. Konsep diri yang positif akan menghasilkan bentuk bentuk tingkah laku yang positif. Tingkah laku yang positif akan mengurangi sifat rendah diri, takut, kecemasan yang berlebihan. (Fitriyani \& Winarti, 2014). Konsep diri merupakan pandangan individu mengenai siapa dirinya yang dapat diperoleh lewat informasi yang diberikan orang lain. Konsep diri merupakan faktor yang menentukan dalam komunikasi antar pribadi, karena setiap orang bertingkah laku sedapat mungkin sesuai dengan konsep dirinya. Pengalaman pengalaman komunikasi terhadap penderita juga menjadi bagian dari hal yang tidak mengenakkan. (Sinaga \& Dr. Welly Wirman , S.IP, 2015). Selanjutnya pengetahuan tentang diri ini digunakan dalam menginterpretasikan informasi dan pengalaman, serta basis pengambilan tindakan dalam kehidupan sehari hari. Dengan kata lain, konsep diri merupakan penentu sikap individu dalam bertingkah laku. Artinya apabila individu cenderung berpikir akan berhasil, maka hal ini merupakan kekuatan atau dorongan yang akan membuat individu menuju kesuksesan. Sebaliknya jika individu berpikir akan gagal, maka hal ini sama saja mempersiapkan kegagalan bagi dirinya. Konsep diri juga terkait dengan fisik, psikologis, pengetahuan tentang diri sendiri, harapan terhadap diri sendiri dan evaluasi diri emosi. (Herani et al., 2012).

Upaya berbagai dukungan dan dampingan terhadap ODHA melalui pemberian konseling, bimbingan, motivasi individual dan juga konseling dan bimbingan bagi keluarga ODHA. Dari aspek dukungan kelompok sebaya juga diperlukan ODHA untuk mendapatkan pemahaman, berbagai pengalaman dan secara bersama dapat memecahkan berbagai permasalahan yang dihadapi. (A. Nelson Aritonang et al., 2014). Dalam kegiatan konseling ODHA mendapatkan pendidikan kesehatan. Sesuai pendapat beberapa referensi tentang pendidikan kesehatan adalah suatu upaya atau kegiatan untuk menciptakan perilaku masyarakat yang kondusif untuk kesehatan.(Nurtanti \& Nita Yunianti Ratnasari, 2016).

\section{Karakteristik Responden ODHA Berdasarkan Tingkat Pekerjaan}

Persentase hasil karakteristik responden ODHA berdasarkan tingkat pekerjaan menunjukkan jumlah tertinggi bekerja sebagai petani yaitu $36,7 \%$ dan terendah tidak bekerja 3,33\%.Dari hasil penelitian dimensi konsep diri berdasarkan pekerjaan menunjukkan bahwa sebagian besar dimensi konsep diri pekerjaan petani lebih tinggi dibandingkan dengan pekerjaan yang lain. Selanjutnya dimensi konsep diri yang rendah tampak pada pekerjaan sebagai swasta/karyawan. Konsep diri ODHA sangat dipengaruhi oleh lingkungan sosialnya. ODHA mengalami berbagai bentuk diskriminasi. Konsep diri ODHA terbentuk melalui hasil interaksi sosial dengan lingkungan sekitarnya seperti istri, keluarga, teman dan orang lain.(Herani et al., 2012).

ODHA yang bekerja sebagai swasta/karyawan akan lebih banyak berhubungan sosial dengan banyak orang ditempat kerjanya dibandingkan petani yang bekerja di ladang atau di sawah, sehingga hal ini akan mempengaruhi kondisi konsep diri. Sesuai hasil penelitian Pius,dkk menunjukkan bahwa konsep diri ODHA di kota Pekanbaru secara keseluruhan berada pada kategori kurang baik. Hasil temuan ini didukung dengan fakta bahwa banyak orang dengan HIV/AIDS sungguh - sungguh ingin mencoba untuk memperbaiki tingkah laku mereka tetapi sikap negatif masyarakat terhadap mereka merubah konsep diri ODHA menjadi ke arah negatif. (Sinaga \& Dr. Welly Wirman , S.IP, 2015). Stigma yang diperoleh ODHA dari dalam diri berupa rasa ketakutan yang bisa berasal dari stigma luar dan stigma dari luar dalam bentuk diskriminasi, intimidasi dan pembiaran akan mempengaruhi ODHA dalam mencari bantuan, menunda pengobatan atau mengakhiri pengobatan. Kepercayaan diri ODHA sangat penting dalam proses pengobatan. (Ardani \& Sri Handayani, RN, 2017). Sebagian besar responden berdasarkan tingkat pekerjaan mempunyai dimensi 
konsep diri yang tinggi yaitu bekerja sebagai petani. Konsep diri positif adalah pemahaman dan penerimaan diri terhadap sejumlah fakta yang bermacam macam sehubungan dengan diri. Individu yang memiliki konsep diri positif akan merancang tujuan - tujuan sesuai dengan realitas, yaitu tujuan yang memiliki kemungkinan besar untuk dicapai, mampu menghadapi kehidupan kedepannya serta menganggap bahwa hidup adalah proses penemuan. (Herani et al., 2012).

Sesuai dengan hasil penelitian Mamat Supri bahwa pada orang dengan HIV/AIDS di Rumah sakit GRHASIA Provinsi Daerah Istimewa Yogyakarta mempunyai gambaran diri, ideal diri, harga diri, penampilan peran dan identitas diri yang positif.(Rohmat, 2011). Dengan bekerja maka ODHA melakukan hubungan sosial dengan orang lain. Berkumpul dalam kelompok dukungan sebaya dapat mempengaruhi fungsi fisiologis sehinga ODHA mampu beradaptasi dengan baik. (Siyoto, Peristiowati, \& Eva Agustina, 2016). Konseling pada ODHA memberikan manfaat terhadap penerimaan diri dan keyakinan bahwa individu masih bermanfaat bagi orang lain terutama bagi penderita HIV/AIDS dan masih bisa berkarya. (Yanndi Afandy, 2017)

Dukungan dari orang lain dapat kita peroleh saat kita berada di lingkungan pekerjaan. Dukungan keluarga mempunyai hubungan yang signifikan dengan konsep diri.(Nurtanti, 2016). Adanya dukungan keluarga dari keluarga juga dapat membantu ODHA untuk mampu mengembangkan konsep diri yang positif dan mampu menjalani kehidupan menjadi lebih baik. ODHA merasa lebih baik saat mereka mendapat dukungan dari keluarga terutama dukungan emosional. (Sinaga \& Dr. Welly Wirman, S.IP, 2015).

Dukungan keluarga memberikan konsep diri yang positif terhadap ODHA. (Fitriyani \& Winarti, 2014)

Wanita dengan HIV/AIDS akan hidup seperti wanita sehat lainnya jika mereka mendapat support dari keluarga mereka, kelompok/masyarakat dan pemerintah. (Marni, RN et al., 2018). Family support are important for life. (Nurtanti \& Handayani,
2017). ODHA yang telah menerima diri akan hidup nyaman dan berdaya, sebaliknya ODHA akan selalu menyesali dan menyalahkan diri sendiri. Proses penerimaan diri pada ODHA ini bersifat dinamis, sewaktu - waktu dapat berubah.(Rasyida, 2008). Hidup penderita HIV dan AIDS mampu menerima diri dan ingin melakukan pekerjaan dengan sepenuh hati. Subyek juga sudah menerima akan keadaan dirinya sekarang sebagai penderita HIV dan AIDS. (Ayu et al., 2016).

\section{SIMPULAN DAN SARAN Simpulan}

Hasil analisis karakteristik responden berdasarkan usia menggambarkan jumlah tertinggi responden adalah usia 41 sampai dengan lebih dari 50 tahun, berjenis kelamin perempuan, sebagian besar berpendidikan sekolah dasar, bekerja sebagai petani. Sebagian besar responden berdasarkan usia mempunyai dimensi konsep diri yang tinggi yaitu pada usia lansia akhir. Berdasarkan jenis kelamin, dimensi konsep diri yang tinggi yaitu perempuan. Pada bagian dimensi kritik diri sebagian besar yang memiliki kritik diri tinggi adalah laki laki. Berdasarkan tingkat pendidikan menunjukkan bahwa sebagian besar dimensi konsep diri responden pendidikan SD lebih tinggi dibandingkan dengan yang lain pada dimensi diri moral etik, diri pribadi, diri sosial dan kritik diri. Pada dimensi diri fisik dan diri keluarga, responden dengan pendidikan SMU mempunyai dimensi konsep diri yang tinggi. Dimensi konsep diri berdasarkan pekerjaan menunjukkan bahwa sebagian besar dimensi konsep diri petani lebih tinggi dibandingkan dengan pekerjaan yang lain. Selanjutnya dimensi konsep diri yang rendah pada pekerjaan sebagai swasta/karyawan. Dari hasil penelitian menunjukkan bahwa sebagian besar tingkat dimensi respon konsep diri pada responden adalah tinggi dari aspek usia, jenis kelamin maupun tingkat pendidikan.

\section{Saran}

Hasil penelitian ini diharapkan bermanfaat dalam upaya peningkatan konsep diri pada ODHA, meningkatkan pelayanan PITC (Provider - initiated testing and counseling) karena PITC merupakan pintu masuk awal 
sebagai program deteksi dini HIV/AIDS. Program ini ditujukan kepada : kelompok tertular (infected people), kelompok berisiko tertular atau rawan tertular (high - risk people), kelompok rentan (vulnerable people), masyarakat umum (general population). Meningkatkan ODHA agar tetap aktif mengikuti kelompok dukungan sebaya (KDS), melakukan kegiatan positif, terbuka dengan orang terdekat, tetap semangat, berjuang dan hidup produktif untu meningkatkan konsep dirinya, menjaga kepatuhan dalam terapi dan pengobatan ARV, tetap tabah dan berserah diri kepada Tuhan Yang Maha Esa, dengan meningkatkan aspek spiritual dan agama. Penelitian selanjutnya diharapkan mengembangkan dengan komponen variabel yang berbeda untuk mengetahui hubungan antara konsep diri terhadap kualitas hidup penderita HIV/AIDS.

\section{DAFTAR PUSTAKA}

A. Nelson Aritonang, P. ., Drs. Nono Sutisna, M., Moch Zaenal Hakim, P. ., Dr. Sakroni, M. P., Drs. Yudi Muryanto, M., \& Dr. Pribowo, M. P. (2014). konsep diri orang dengan HIV/AIDS (ODHA). Sekolah Tinggi Kesejahteraan Sosial (STKS).

Ardani, I., \& Sri Handayani, RN, Ms. (2017). Stigma terhadap Orang dengan HIV / AIDS ( ODHA ) sebagai Hambatan Pencarian Pengobatan: Studi Kasus pada Pecandu Narkoba Suntik di Jakarta. Buletin Penelitian Kesehatan, 45, 81-88. Retrieved from http://dx.doi.org/10.22435/bpk.v45i2.6 042.81-88।

Ayu, I., Putri, K., \& Tobing, H. (2016). Gambaran Penerimaan Diri Pada Perempuan Bali Pengidap HIV-AIDS, 3(3), 395-406.

Fitriyani, E. N., \& Winarti, S. A. (2014). Konsep Diri dengan Kejadian Depresi pada Pasien Gagal Ginjal Kronik yang Menjalani Hemodialisa di RSUD Panembahan Senopati Bantul, 2(3), 122-127.

Herani, I., Sarikusuma, H., \& Hasanah, N.
(2012). Konsep diri orang dengan HIV dan AIDS ( ODHA ) yang menerima label negatif dan diskriminasi dari lingkungan sosial Self-concept of people with HIV and AIDS ( ODHA ) who experience negative labelling and discrimination from their social environment. Psikologia-Online, 7, No 1(1), 29-40. Retrieved from file:///D:/JURNAL HIV KEMAS 2019/JURNAL

HIV/labellingpadaodha(1).pdf

Ibrahim, K., H, Y. K., Rahayuwati, L., \& Nurmalisa, B. E. (2017). Hubungan antara Fatigue, Jumlah CD4, dan Kadar Hemoglobin pada Pasien yang Terinfeksi Human Immunodeficiency Virus ( HIV ) The Correlation of Between Fatigue, CD4 Cell Count, and Hemoglobin Level among HIV / AIDS Patients, 5, 271-280.

Indonesia, K. K. R. (2017). Laporan Perkembangan HIV-AIDS \& Penyakit Infeksi Menular Seksual (PIMS) Triwulan I Tahun 2017.

Isni, K. (2016). Dukungan Keluarga, Dukungan Petugas Kesehatan, Dan Perilaku Ibu HIV dalam Pencegahan Penularan HIV/AIDS ke Bayi. Jurnal Kesehatan Masyarakat, 11(2), 18581196. Retrieved from https://journal.unnes.ac.id/nju/index.ph p/kemas/article/view/4014/4682

Kesehatan, K. (2018). Hasil Utama Riskesdas 2018.

Marni, RN, Ms., Susana Nurtanti, RN, Ms., Sri Handayani, RN, Ms., Nita Yunianti Ratnasari, RN, Ms., \& Tantut Susanto,MN,RN MN,RN,PHN, P. (2018). The Lived Experience of Women with HIV / AIDS : A Qualitative Study. International Journal of Caring Sciences, 11(3), 1475-1482.

Nurtanti, S. (2016). Dukungan Keluarga Terhadap Perkembangan Psikologi: Konsep Diri Pada Anak Usia Sekolah Dasar Di Desa Lebak Kecamatan Pracimantoro. Akademi Keperawatan 
17 Karanganyar, 4 Nomor 1(23386800), 72-. Retrieved from http://akper17.ac.id/ejurnal/download/4-jurnal-akpertujuhbelas/72-susana-nurtanti.html

Nurtanti, S., \& Handayani, S. (2017). Human Characteristics, Causality, Methods, and Public Opinion on Suicide: Case Report. Proceeding Book The International Conference on Translational Medicide and Health Sciences (ICTMHS), September(978602-5560-40-8). Retrieved from https://ictmhs.fk.undip.ac.id/wpcontent/uploads/2017/02/proceeding20 17.pdf

Nurtanti, S., \& Nita Yunianti Ratnasari. (2016). Efektivitas Penerapan Pendidikan Kesehatan Pola Asuh Sehat Mental Terhadap Perkembangan Psikososial Anak Usia 3 - 6 Tahun. Profesi, 13, 31-37. https://doi.org/http://dx.doi.org/10.265 76/profesi.117

Rasyida, A. N. U. R. (2008). Faktor - faktor yang mempengaruhi (orang dengan HIV-AIDS). Universitas Katolik Soegijapranata.

Rohmat, M. S. (2011). Gambaran Konsep Diri Pada Orang Dengan HIV/AIDS di Rumah Sakit Grhasia Provinsi Daerah Istimewa. Stikes Aisyiyah Yogyakarta, $1-18$.

Sinaga, P. A., \& Dr. Welly Wirman , S.IP, M. S. (2015). Pembentukan Konsep Diri Orang Dengan HIV/AIDS (ODHA) Di Kota Pekanbaru Dalam Perspektif Fenomenologi. JOM FISIP Vol. 2 No. 2 - Oktober, 2(2), 1-15.

Siyoto, S., Peristiowati, Y., \& Eva Agustina. (2016). TEORI ADAPTASI CALLISTA ROY ( Coping Mechanism on People Living with HIV Using Theory of Adaptation Callista Roy ). Jurnal Ners Stikes Surya Mitra Husada Kediri, 11, 256260.

SurahmaWahyu, Taufik, \& Asmidirlilyas.
(2012). Konsep diri dan Masalah yang dialami orang terinfeksi HIV/AIDS, 1(3), 1-12. Retrieved from http://ejpurnal.unp.ac.id/index.php/kon selor

Tasa, Y., Ludji, I. D. R., \& Rafael Paun. (2016). Pemanfaatan Voluntary Counseling And Testing Oleh Ibu Rumah Tangga Terinfeksi Human Immunodeficiency Virus. Jurnal Kesehatan Masyarakat, 11(2), 18581196. Retrieved from http://journal.unnes.ac.id/nju/index.ph $\mathrm{p} /$ kemas

Yanndi Afandy. (2017). Penerimaan Diri Pada Penderita HIV/AIDS di Yogyakarta. Jurnal Fakultas Psikologi Universitas Ahmad Dahlan. 